\title{
Wadden Sea mussel beds invaded by oysters and slipper limpets: competition or climate control?
}

Received: 2 November 2005/ Accepted: 4 January 2006/Published online: 7 March 2006

(C) Springer-Verlag and AWI 2006

\begin{abstract}
Introduced species are often considered to be a threat to residents, but not all reciprocal trends may reflect species interaction. In the northern German Wadden Sea, native mussel Mytilus edulis beds are declining and overgrown by introduced Pacific oysters Crassostrea gigas and slipper limpets Crepidula fornicata. We review the population development of the three species and analyse whether the invading species may be responsible for the decline of native mussels. The Pacific oyster predominately settles on mussel beds in the intertidal and the slipper limpet dominates around low water line. We compare the development of mussels and invaders in two subregions: mussel beds near the islands of Sylt and Amrum decreased both in the presence (Sylt) and absence (Amrum) of the two invading species and more detailed investigations could not confirm a causal relationship between the increasing invaders and decreasing mussel beds. There is evidence that the decline of mussel beds is mainly caused by failing spatfall possibly due to mild winters, whereas the increase in slipper limpets and oysters is facilitated by mild winters and warm summers, respectively. We conclude that changing species composition is a result of the climatic conditions in the last decade and that there is no evidence yet that the exotic species caused the decline of the natives. It remains an open question whether the species shift will continue and what the consequences for the native ecosystem will be.
\end{abstract}

Communicated by K. Reise

G. Nehls $(\bowtie)$

BioConsult SH, Brinckmannstr. 31, 25813, Husum, Germany

E-mail: g.nehls@bioconsult-sh.de

S. Diederich $\cdot$ D. W. Thieltges $\cdot$ M. Strasser

Alfred Wegener Institute for Polar and Marine Research,

Wadden Sea Station Sylt, Hafenstr. 43,

25992, List/Sylt, Germany

\section{Introduction}

Invasive species are often considered to be threats to native flora and fauna. Having evolved under different environmental and ecological conditions, some species introduced into new habitats may find it much easier to cope with environmental and ecological conditions than in their native ranges. Especially the absence of predators, parasites or strong competitors may release a species from constraints and enforce a rapid expansion in the new habitat, often at the cost of native species (Maron and Vila 2001; Keane and Crawley 2002; Torchin et al. 2003; Colautti et al. 2004). In addition, environmental factors like local climate play an important role in the establishment of introduced species (Stachowicz et al. 2002). If suitable conditions are met, an invader can strive and may exert negative impacts on native biota (Carlton et al. 1990; Kideys 2002). In changing climate it may even be easier for an invader to match the new conditions than for a resident to adapt itself.

The Wadden Sea is a large intertidal ecosystem along the eastern shore of the North Sea which has been shown to be highly dynamic and very receptive for introduced species (Reise et al. 2005). In ecological terms, the Wadden Sea benthos is dominated by filter feeding organisms which take the main share of energy turnover (Baird et al. 2004). Interestingly, even within the filter feeding assemblage, invading species play a very important role and the introduced clam Mya arenaria and the razor clam Ensis americanus are today highly abundant species (Reise et al. 2005). Similarly, the Pacific oyster Crassostrea gigas and the filter feeding slipper limpet Crepidula fornicata have strongly increased in recent years and both species form dense beds or reefs in the Wadden Sea, where until recent, mussel beds Mytilus edulis were the only biogenic structures forming reef-alike structures on the soft sediments. Both Pacific oyster and slipper limpet may be considered as threats to native mussels, which initially provide the main substrate for the two epibiotic species. Indeed, 
mussel beds have shown a recent decrease in abundance and this suggests a negative impact of the two introduced species on the native mussels. However, a potential causal link between mussel decrease and invader increase has so far not been documented and it may well be that the observed trends are not causally linked but based on coincidence. In this case, other factors like climate may explain the observed reciprocal trends.

In this paper we describe and review the expansion of Pacific oysters and slipper limpets in the northern German Wadden Sea (Schleswig-Holstein/Nordfriesland) and the decline of native blue mussel beds based on data from ongoing monitoring programs and ecological studies of species interaction. We will show that changing environmental conditions and not competition between the introduced and native species are the driving force for the observed change in mussel bed communities.

\section{Methods}

Blue mussel (Mytilus edulis)

Intertidal mussel beds are monitored on a regular basis in the Wadden Sea National Park of Schleswig-Holstein and the expansion of introduced species has been recorded during this work. The scope and methods of monitoring of mussel beds have been described in detail in the manual of the Trilateral Monitoring and Assessment Program (TMAP) (CWSS 1997; see also Herlyn 2005; Vlas et al. 2005) and are outlined here only briefly. Intertidal blue mussel beds have been mapped annually since 1998 by means of aerial pictures (scale $1: 15,000$ or $1: 25,000$ ) and ground-based mapping using GPS following standard procedures outlined in the TMAP manual (Nehls 2004). In a similar preceding monitoring program, mussel beds have been mapped from 1988 to 1994 (Ruth 1994) and data have been modified later after analysing aerial photographs from that time (Stoddard 2003).

Samples of mussels and associated fauna are taken by core sampling on the mussel beds. As a standard, 12 samples with a core sampler of $150 \mathrm{~mm}$ diameter are taken on about 30-40 mussel beds. Mussel beds in the List tidal basin are sampled twice annually (May and September). Samples are taken randomly on the mussel beds and washed through a sieve with $1 \mathrm{~mm}$ mesh size. Length is measured using an electronic calliper. Biomass is calculated as live wet weight (including the water enclosed in the living mussels) using the following equation:

$W=2.718^{\wedge}(2.919(\ln L)-8.764)$,

where $W$ is the weight in grams and $L$ the length in millimetre.

\section{Slipper limpet (Crepidula fornicata)}

Associated fauna of the mussel beds is sampled on two mussel beds in the List tidal basin in September using a
$100 \mathrm{~mm}$ core sampler which is driven about $30 \mathrm{~cm}$ deep into the mussel layer. Samples are washed through a $1 \mathrm{~mm}$ sieve and stored in $8 \%$ formaldehyde and analysed in the lab of the benthological working group of the Rendsburger Werkstätten, Rendsburg, Germany, using standard procedures for species identification and determination of biomass.

\section{Pacific oyster (Crassostrea gigas)}

Pacific oysters are included in the above-described sampling but due to the low densities in the early years of the development, oyster abundances were randomly determined using a $50 \times 50 \mathrm{~cm}^{2}$ frame or a $25 \times 25 \mathrm{~cm}^{2}$ frame. As long as oyster abundances were low, 50 samples with the bigger frame were taken per mussel bed but with increasing oyster abundance (10-50 ind. $/ \mathrm{m}^{2}$ and more) fewer samples were taken and the smaller frame was used. Samples were washed through a $1 \mathrm{~mm}$ sieve and the length of all oysters was measured with an electronic calliper.

Oyster biomass was calculated from average live wet weight of oysters (Diederich unpublished data).

\section{Results and discussion}

\section{Mussel beds in the northern German Wadden Sea}

Mussel beds (M. edulis) may form stable and long-living communities (Obert and Michaelis 1991; Reise et al. 1994; Dankers et al. 1999; Nehls and Ketzenberg 2002). Annual mapping since 1988 showed that mussel beds cover about $1 \%$ of the tidal flats in the North Frisian Wadden Sea when the population is at high levels (Ruth 1994); however, the distribution differs regionally (Fig. 1). Within the Wadden Sea of Schleswig-Holstein mussel beds have been present on almost 200 locations in the last decades, but only about one-third of these locations are covered with persistent mussel beds (Nehls 2004). Sheltered areas behind islands or high sandflats are particularly suitable because they offer protection against storms which are a very important factor in shaping the distribution and dynamics of mussel beds in the Wadden Sea (Nehls and Thiel 1993). The sheltered areas behind elongated islands such as Amrum and Sylt stretching from south to north thus harbour major parts of the mussel population of the Wadden Sea of Schleswig-Holstein (Fig. 1).

Recent decline of mussels and increase of oysters and slipper limpets

The area of intertidal mussel beds in the Wadden Sea of Schleswig-Holstein decreased from about 1,500 ha in 1988 to 500 ha in 2004, and total biomass (live wet weight) decreased from a maximum of 60,000 t in 1989 


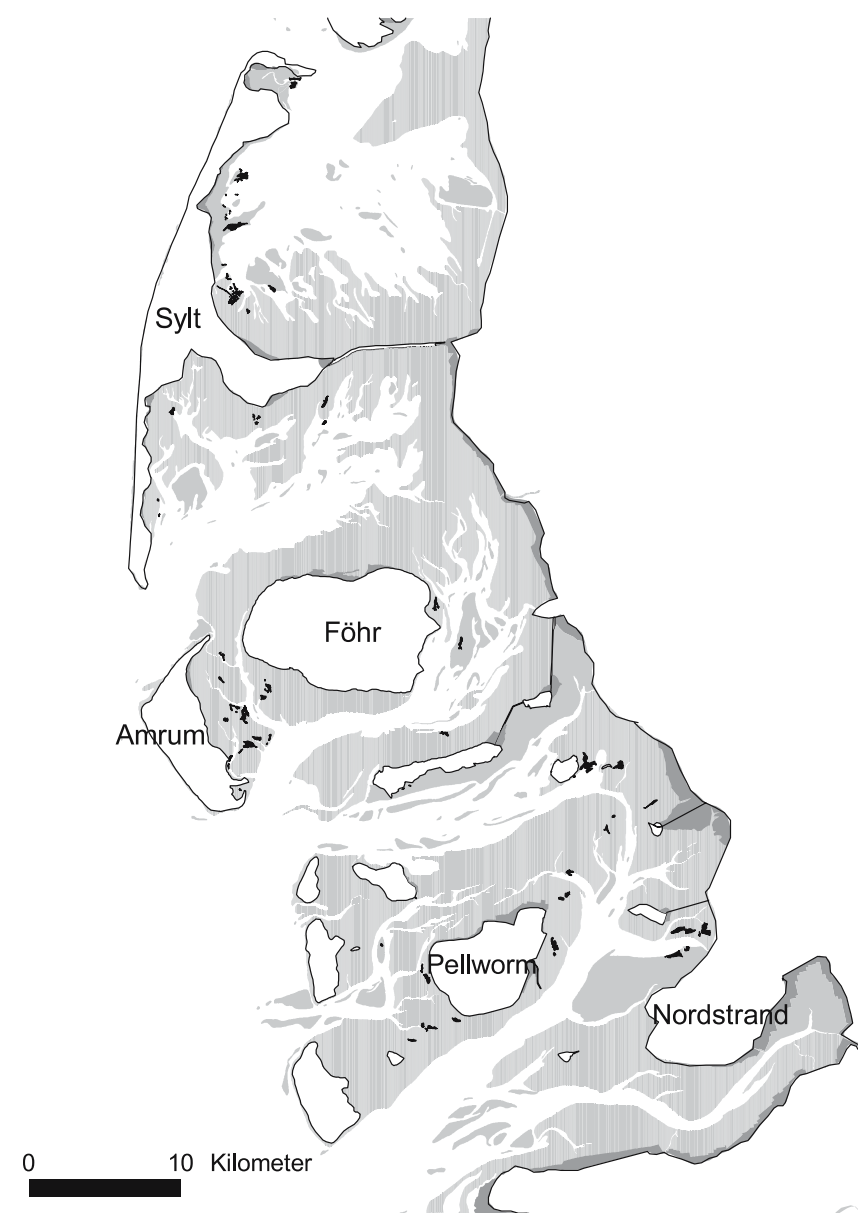

Fig. 1 Location of mussel Mytilus edulis beds (black) in the northern German Wadden Sea of Schleswig-Holstein in 2004. Tidal flats are shaded in light grey and salt marshes in dark

to $12,000 \mathrm{t}$ in 2004 (Fig. 2). The decline occurred almost continuously since 1988 except for 1999 and 2003 when some new mussel beds were established from spatfalls in the southern part of the study area. The decline of the mussel beds was evident in all parts of the study area. In some locations it could be attributed to single storm events as some beds vanished in the course of a winter obviously being washed away in strong storms; however, in sheltered areas also mussel beds thinned out, declined in area and gradually vanished.

During the same time the Pacific oyster $C$. gigas and the American slipper limpet $C$. fornicata increased in abundance on the mussel beds. Pacific oysters are cultured in the List tidal basin in the northern part of the Wadden Sea since 1986 and from 1991 onwards this species is found on natural mussel beds in the area (Reise 1998). Oysters spread since then and meanwhile have colonised almost all mussel beds in the List tidal basin. Since 1995, Pacific oysters are also found on mussel beds near the island of Amrum, which became the second centre of oyster distribution in the Wadden Sea of Schleswig-Holstein. Since the year 2000, oyster abundance increased in all areas of the Wadden Sea of
Schleswig-Holstein and it is likely that the spread in these years was facilitated by a succession of anomalously warm summers and an influx of larvae from westernmore areas of the Wadden Sea where oysters are also spreading (Wehrmann et al. 2000; Diederich et al. 2005). By 2004 mean oyster abundance was 290 ind. $/ \mathrm{m}^{2}$ on mussel beds with a maximum of 600 oysters $/ \mathrm{m}^{2}$ (Fig. 3). The increase in abundance was caused by strong oyster spatfalls in 2001, 2002 and 2003 in the List tidal basin and a strong spatfall in 2003 in most parts of the Wadden Sea of Schleswig-Holstein. Oysters are since then found on almost all mussel beds but densities $>1$ per square metre are still restricted to the Lister Deep and the mussel beds between the islands of Amrum and Föhr (Fig. 4). In the first years of mussel bed colonization, single oysters attached mainly to mussels. As abundances increased, oysters also settled onto each other forming clumps (Diederich 2005a). In areas of high density, the oysters finally form dense layers and create a solid surface. In these areas, some former mussel beds turned into oyster reefs (Fig. 5).

The American slipper limpet, originating from the east coast of North America, was first observed in the Wadden Sea on flat oyster (Ostrea edulis) grounds around the island of Sylt in the 1930s where it was introduced with seed oysters (Ankel 1935). In the following years it spread to other oyster beds (Werner 1948) and also to mussel beds after the native oyster populations vanished (Thieltges et al. 2003). Today, C. fornicata is abundant in all parts of the Wadden Sea and found on almost all mussel beds. It is characteristically found in the lower parts of the mussel beds close to low water line and in the shallow subtidal (Thieltges et al. 2003). In the cold winters 1978/1979 and 1995/1996 C. fornicata suffered from high mortality but recently started to increase in abundance again (Thieltges et al. 2004, Fig. 3). Samples of the total macrofauna of mussel beds in different parts of the study area revealed mean abundance values on single mussel beds ranging from 0 (no specimen found in 5 years) to 318 ind. $/ \mathrm{m}^{2}$. Peak values in single years reached $800 \mathrm{ind} . / \mathrm{m}^{2}$ and $50 \mathrm{~g}$ AFDW $/ \mathrm{m}^{2}$. In the List tidal basin, $C$. fornicata has achieved dominance on some parts of the mussel beds on which the few remaining mussels are now hidden by a dense layer of the slipper limpet (Fig. 5).

Negative impact of oysters and slipper limpets on native mussels?

The coincidence of the observed decrease of mussels and the increase of oysters and slipper limpets may be caused by a negative impact of the two invaders on the native mussels since both introduced species have been described to negatively affect blue mussels in the northern Wadden Sea (Diederich 2005b; Thieltges 2005).

As the oysters need hard substrates for settlement, they are attaching themselves to the shells of living and dead mussels, thereby overgrowing their basibionts. 

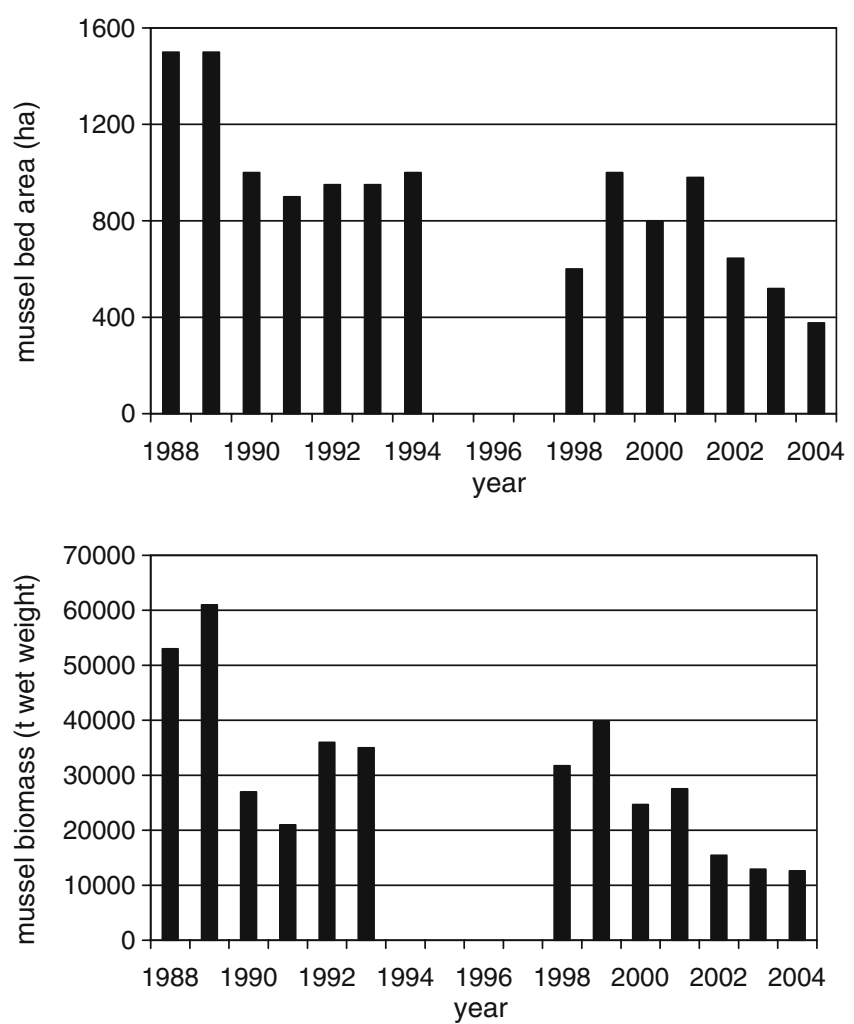

Fig. 2 Development of mussel bed area (ha) and biomass (t wet weight) in the northern German Wadden Sea from 1988 to 2004

Especially as the oysters grow faster and reach about 3-4 times the size of mussels, they might be stronger competitors if space and/or food are limiting (Diederich 2005b). Space for soft bottom organisms is not limited in the Wadden Sea but habitat for organisms requiring hard substrates is scarce and mainly restricted to mussel beds. Mussel beds are generally confined to semi-exposed locations, where they are sheltered from wave action, but where currents are still high enough to guarantee adequate food supply (Brinkman et al. 2002). The higher growth and survival rates of $C$. gigas compared to M. edulis (Diederich 2005b) might therefore lead to a competitive advantage of the introduced species and to a replacement of mussel beds by oyster reefs. This would especially be the case if food limitation might occur in dense assemblages of filter feeders as has been described for other areas (Dame et al. 1984; Fréchette et al. 1989; Peterson and Black 1991). However, the mussels might be able to regain space by settling on top of the newly established oyster reefs provided a strong mussel spatfall would occur (Diederich 2005a).

Being a filter feeder, C. fornicata has been suspected to compete with native filter feeders like oysters and mussels (Orton 1927; Ankel 1935; Werner 1948; Korringa 1951) but experimental proofs were not provided. Recent small-scale field experiments on trophic competition between $C$. gigas or M. edulis and C. fornicata failed to provide evidence for food competition (Montaudouin et al. 1999; Thieltges 2005). However, blue mussels with C. fornicata epigrowth suffered from 3 to 5 times lower growth and a fourfold to eightfold reduction in survival compared to unfouled mussels. This may be caused by strongly enhanced byssus production of the mussels: the stacks of $C$. fornicata cause additional drag forces prompting the basibiont to invest more energy in the attachment to its substrate, which may reduce its overall fitness (Thieltges 2005).

\section{No evidence for large-scale displacement}

To assess the possible impact of the invaders on mussel beds we compare the development of two sheltered areas: (a) the List tidal basin and (b) the tidal flats between the islands of Amrum and Föhr. Both areas harboured extensive and dense mussel beds in the late 1990s. In 1999, mussel bed area reached 205 ha in the List tidal basin and 250 ha between Amrum and Föhr, which represent a coverage of 2.7 and $4.8 \%$ of the tidal flats of these basins, respectively. This is well above the average for the Wadden Sea of Schleswig-Holstein which attained $0.8 \%$ in 1999 . Also, biomass values within the beds and the proportion actually covered by mussels showed high values compared to other areas, so

a)
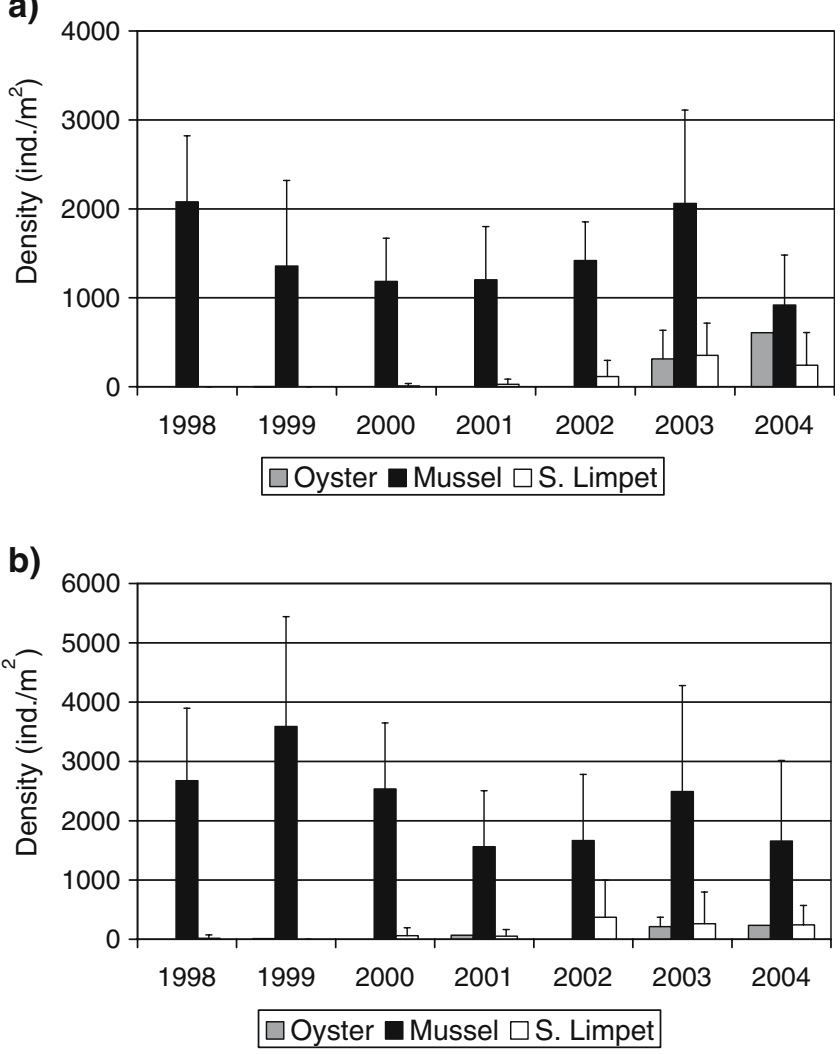

Fig. 3 Abundance (+ SD) of mussels, Pacific oysters (Crassostrea gigas) and slipper limpets (Crepidula fornicata) on two mussel beds (a, b) in the List tidal basin from 1998 to 2004 

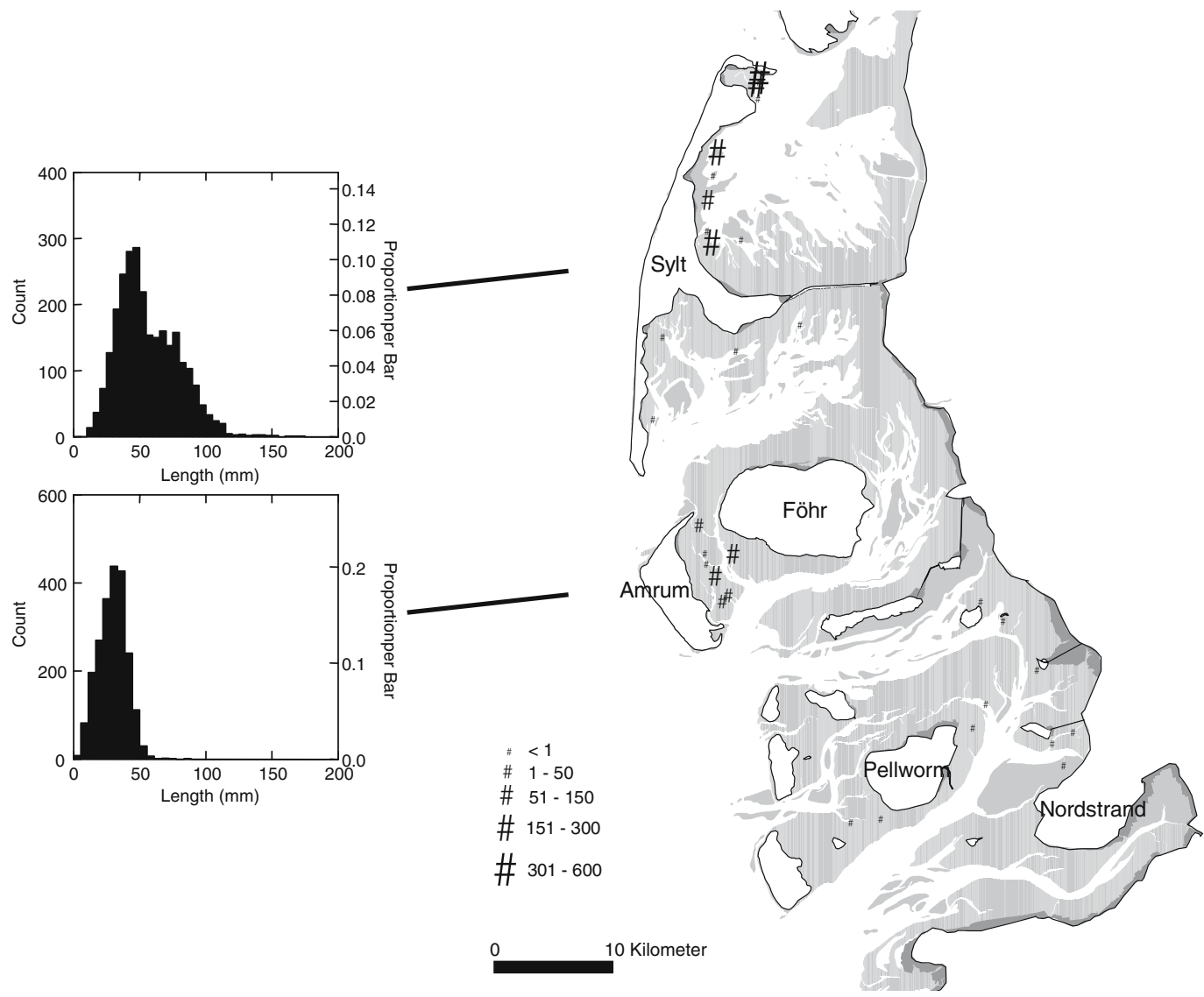

Fig. 4 Abundance and distribution of oysters in the northern German Wadden Sea in 2004. The two graphs on the left show the lengthfrequency distribution of oysters on the mussel beds near Sylt (top) and Amrum (bottom). Dot size indicates oysters $/ \mathrm{m}^{2}$

that both subareas were characterised by holding extensive and well-established mussel beds in the late 1990s. In both areas, mussel beds strongly decreased after 1999 to about 80 ha in 2004. The coverage within the beds and the biomass in the covered parts of the beds decreased as well, so that the total biomass in the List tidal basin decreased by $70 \%$ and in the area between Amrum and Föhr by $80 \%$. In both areas hardly any spatfall, which could have enlarged the mussel beds, occurred throughout the study period.

Interestingly, the development of oysters differed greatly between the two areas (Fig. 4). In the List tidal basin, where the only commercial oyster farm of this region is located, the spread of the Pacific oyster started in 1991 and on parts of the mussel beds a strong spatfall, which greatly increased the abundance, was visible in 1998. Until 2004, the density of the Pacific oyster on the mussel beds in the List tidal basin increased to about 290 ind. $/ \mathrm{m}^{2}$, locally reaching $600 \mathrm{ind} . / \mathrm{m}^{2}$. In contrast, oyster abundance remained comparably low around Amrum. In 1998, oysters were found on most mussel beds in this area but abundances did not exceed 1 ind./ $\mathrm{m}^{2}$. Abundance of oysters apparently decreased in the following years, until a strong spatfall reached most mussel beds in 2003. The differences in oyster develop- ment of the two areas may reflect different sources of larval supply: the fast growing population in the List tidal basin was continuously supplied with larvae from the oyster farm, which was very important as long as the oyster population was not self-sustainable. In the area behind Amrum no continuous supply occurred. Thus, development of the population was retarded at an early stage. When in 2003 oyster spatfall occurred on most mussel beds outside the List tidal basin one may assume that there was an influx of larvae from more distant oyster populations. Still, in 2004 the density of oysters on the mussel beds near Amrum reached on average only 60 ind. $/ \mathrm{m}^{2}$, which is far less than the average of 290 ind. $/ \mathrm{m}^{2}$ in the List tidal basin. As oysters on the mussel beds near Amrum were dominated by small and young oysters in 2004 (Fig. 4) total biomass reached only about $30-50 \mathrm{t}$ which is lower than the estimated $2,000-3,000 \mathrm{t}$ on the mussel beds in the List tidal basin. Considering the very slow development of oyster population near Amrum, it can be excluded that the oysters had a significant impact on the mussel beds; still the decline of $M$. edulis occurred in a similar way as in the List tidal basin where oysters were more abundant, suggesting that mussel decline occurred independent of oysters. 

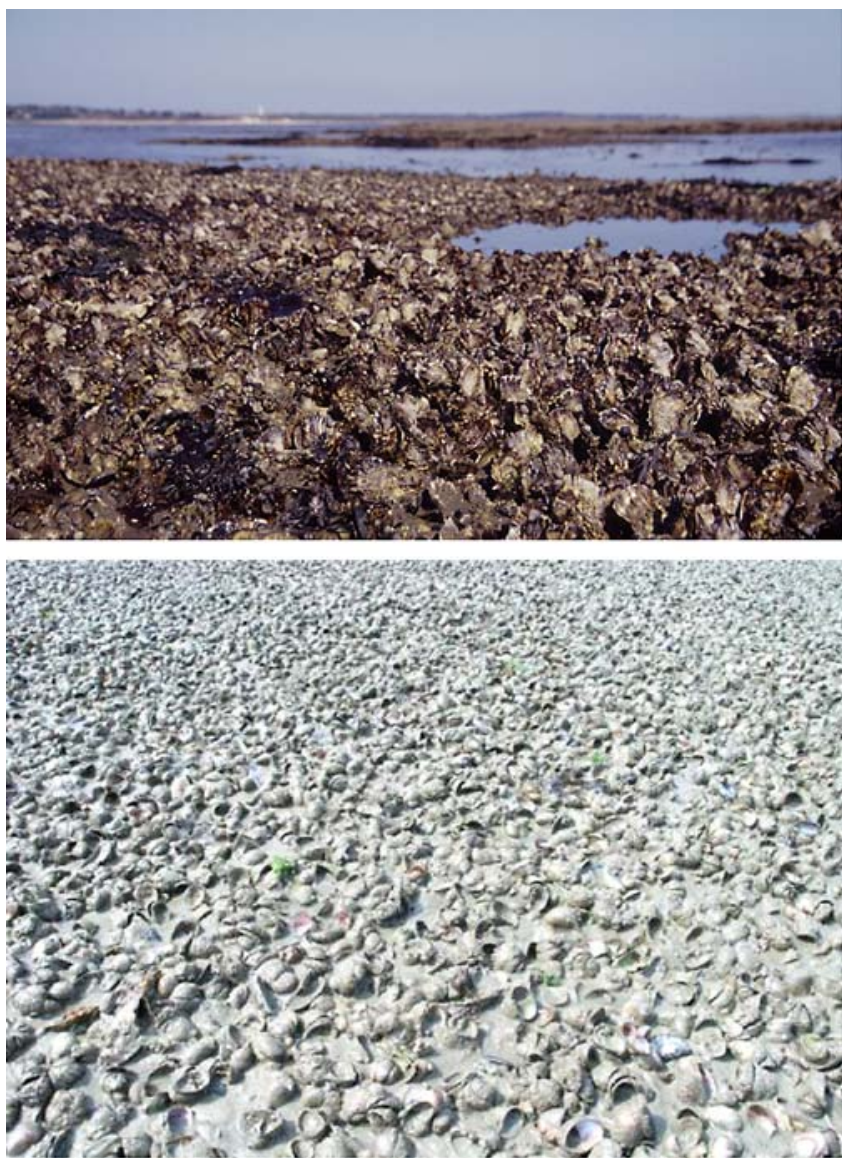

Fig. 5 Oyster reef (top) and layer of slipper limpets (bottom) in the List tidal basin, island of Sylt, May 2005

In addition, we found no evidence that oysters are the cause of declining mussel beds. On a mussel bed south of List we took 35 samples in September 2004 in all parts of the mussel beds and found a positive correlation between oyster density and mussel biomass $\left(R^{2}=0.08\right.$; $P<0.001$ ) (Fig. 6). This is remarkable, as the oyster density on this bed was high and reached 210 oysters $/ \mathrm{m}^{2}$ on average. Although a positive correlation does not exclude negative effects of oysters on mussels, it shows that an increase of oysters does not necessarily have to result in a decline of mussel abundances.

Comparing the spread of oysters with that of mussel bed area in 1999 it is also apparent that oysters only occupy parts of the former mussel bed area. In the List tidal basin, in 2004 an estimated $20 \%$ of the mussel beds were occupied by dense oyster reefs as shown in Fig. 5. On the mudflats near Amrum no such dense oyster reefs were present in 2003 and 2004, so most of the former mussel bed area was neither covered by mussels nor by oysters. The situation with $C$. fornicata is rather similar. This species is generally less abundant than mussels or oysters and the densities on the mussel beds are too low in most areas to exert a negative impact on the mussel population. Dense layers as shown in Fig. 5 were only found on the lower parts of some beds in the List tidal basin in the transition zone between the intertidal and subtidal. In these areas a displacement of mussels by $C$. fornicata cannot be excluded. However, the area occupied by dense $C$. fornicata layers still covers an insignificant proportion of the former mussel beds.

Divergent recruitment strategies and the importance of climatic conditions

The results shown above indicate that the two invaders are not responsible for the observed decline of mussel beds, although in parts of the Wadden Sea they have started to occupy the place of the mussel beds. We argue that two other factors are primarily responsible for the observed reciprocal trends: changes in winter mortality and temperature effects on reproduction.

It appears to be a common feature of $M$. edulis in the Wadden Sea that cold winters play an important role in the population dynamics. Although mussel beds often suffer high mortalities in cold winters, recruitment tends to be very strong in the following year so that mussel beds are rejuvenated or newly formed (Dankers et al. 1989; Strasser et al. 2001). A strong spatfall which rebuilds a former mussel bed or forms a new mussel bed on the mudflat may exceed 50,000 recruits $/ \mathrm{m}^{2}$ in the settling phase, but these events are rare and occur predictably only after cold winters (Dankers et al. 1989). The main reason behind this often observed phenomenon seems to be a temporal mismatch of mussel recruits and their main predators, shrimps and crabs: after a cold winter, predators are late in entering the tidal flats so that mussel recruits face reduced predation rates (Strasser and Günther 2001; Strasser 2002; Beukema and Dekker 2005). After mild winters, spatfall predominantly occurs into existing beds and reaches densities of $1,000-3,000$ recruits $/ \mathrm{m}^{2}$. This is usually not enough to form new mussel beds but used to be sufficient to compensate for losses in the existing beds so that these could persist for long times (Nehls and Ketzenberg 2002). In the study period most mussel beds were built up by strong spatfalls in 1987 and 1996, after the last

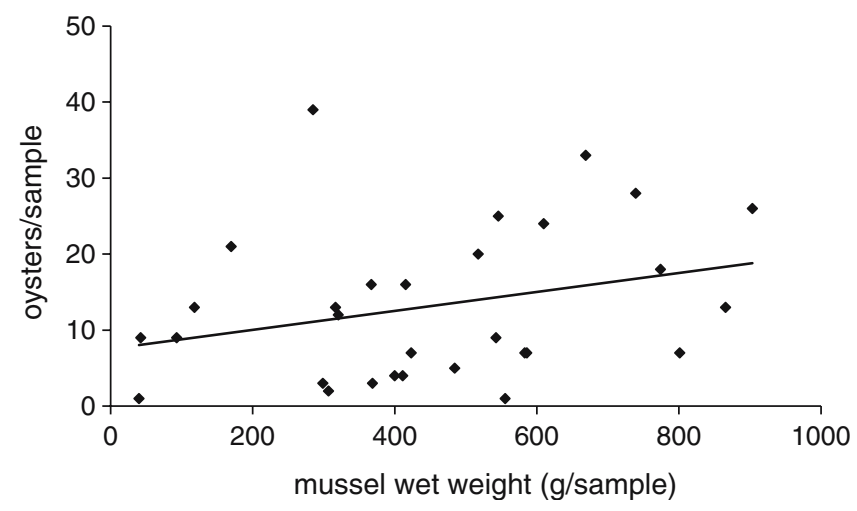

Fig. 6 Correlation of oyster density and mussel biomass on a mussel bed in the Lister Deep in September $2004(n=30$, frames $\left.25 \times 25 \mathrm{~cm}^{2}\right)$ 
two strong winters in the area (Nehls 2004; Nehls and Ruth 2004). Only in 1999 and 2003 spatfall was strong enough to allow the establishment of new mussel beds, but this occurred only in the southern parts of the study area and not near Sylt and Amrum where oysters started spreading on the mussel beds (Nehls 2004; Nehls and Ruth 2004). On mussel beds in the List tidal basin the mean density of mussel recruits $(<15 \mathrm{~mm})$ from 1998 to 2003 was only about 600 ind. $/ \mathrm{m}^{2}$, which is not even sufficient to compensate for losses from predation and other sources of mortality. In conclusion, failing recruitment due to a lack of cold winters since 1995/1996 thus appears to be the main reason for the decline of the mussel beds.

Contrary to mussels, winter temperatures are less important for oyster population development. Here it seems to be the summer water temperature rather which determines the recruitment success (Diederich et al. 2005). Even though there are regional differences, Pacific oysters are known to depend on water temperatures above $20^{\circ} \mathrm{C}$ for successful recruitment (Korringa 1976; Mann 1979; Buroker 1985). In the northern Wadden Sea, all high recruitment events occurred in years with exceptionally high water temperatures in late summer, when spawning and settlement occurs (Diederich et al. 2005). Predation on oyster recruits seems to play a minor role. Juvenile oysters show very high survival rates in the field, and prey choice experiments with the main benthic predators, shore crabs and starfish, revealed that both predators strongly prefer mussels to oysters (Diederich 2005c). Therefore, predation does not seem to be important for oyster populations in the Wadden Sea. In addition, winter mortality also seems to play only a minor role. About $66 \%$ of the oyster population in the List tidal basin survived the anomalous severe winter of 1995/1996 (Reise 1998). Not restricted by cold winters, Pacific oysters thus take the advantage of warm summers in the Wadden Sea without being constrained by predation.

As in mussels, the severity of winters is important for population development in slipper limpets. However, in this case a strong winter has no beneficial effects but is devastating for slipper limpet populations. Field observations and laboratory experiments showed that $C$. fornicata is highly susceptible to cold temperatures and freezing (Werner 1948; Walne 1956; Thieltges et al. 2004). In the northern Wadden Sea, the severe winters of 1978/1979 and 1995/1996 led to a drastic decrease of the local C. fornicata population (Buhs and Reise 1997; Thieltges et al. 2004). Such high mortality rates are in strong contrast to low winter mortality rates of $C$. fornicata observed in southern Europe where cold winters are absent and hence population densities are at least one magnitude higher (Blanchard 1997; Thieltges et al. 2004). It seems that in the northern Wadden Sea, cold winters regularly decimated the invader and kept abundances relatively low (Thieltges et al. 2004). The recent series of mild winters may hence explain the observed increase in population size. It is not known which factors regulate the recruitment success of slipper limpets in the Wadden Sea, but the observed gradual increase on the mussel beds in the List tidal basin indicate that slipper limpets are less dependent on single strong spatfalls as the other species. As in Pacific oysters, predation pressure on slipper limpets in the Wadden Sea appears to be rather low (Thieltges et al. 2004), which might enable this species to reproduce successfully even in the presence of predators such as shrimps and crabs.

The most important difference between the three species appears to be the degree to which they are prone to predation. The development of mussels, as the development of other native bivalves of the Wadden Sea, is severely controlled by predators (see Reise 1985). When predators like crabs and shrimps are abundant, they are likely to clear the mudflats from mussel spatfall and other bivalves (Reise 1985; Beukema and Dekker 2005). As a consequence, mussels and other native bivalves of the Wadden Sea can only reproduce successfully on a large scale when predators are rare. Winter water temperature controls the timing of predators moving onto the tidal flats and thus regulates the reproductive success of mussels and other bivalves (Strasser and Günther 2001; Strasser 2002; Beukema and Dekker 2005). If they are late after a cold winter, mussels have an advantage. In a warming climate with less frequent cold winters, reproductive success of mussels will be reduced and mussels are likely to decrease as observed now in a period of mild winters. In contrast, Pacific oysters and slipper limpets are not restrained by predators. Especially the Pacific oyster can thus take advantage of warming summer temperatures which is impossible for mussels. In a warming Wadden Sea, oysters are thus likely to increasingly occupy the place of the blue mussel - not as a result of competitive displacement but rather as an occupation of empty space. Similarly, slipper limpets will profit from warmer winters as this reduces their winter mortality and as they are little affected by predators.

\section{Conclusions}

The decline of mussel beds in the northern German Wadden Sea and the increase of the introduced Pacific oyster and slipper limpet populations are processes linked to recent climatic conditions. The decrease of the native mussel population is not caused by displacement due to the invaders. Mussels may well suffer from competition for food and space with the introduced Pacific oysters and slipper limpets. However, up to now these processes are only relevant at a small scale and not the cause for the observed large-scale changes from mussel beds to oyster reefs or limpet layers. The main reason for declining mussel beds is the failure of recruitment, which is assumed to be initiated by warm winters, resulting in synchronised settling of mussels and their main predators in the Wadden Sea. 
The spread of oysters is facilitated by warm summers, as water temperatures above $20^{\circ} \mathrm{C}$ are necessary for spawning. As oysters are little prone to predators, settlement in summer when the populations of predators on young bivalves are high is not a problem. In this respect, oysters have a clear advantage compared to other bivalves of the Wadden Sea.

It can be concluded that the Pacific Oyster, being tolerant to cold winters and taking advantage of warm summers, has the potential to replace mussel beds in the Wadden Sea, as oysters tend to settle in the same locations and on the same tidal level as mussels. The development of the slipper limpet is more restricted to the transition zone of the intertidal and subtidal. Thus, this species will most likely occupy only a small part of the former range of mussel beds. As slipper limpets are very sensitive to cold winters, the fate of its population development will depend much on the duration of the ongoing series of mild winters.

Acknowledgements The authors acknowledge the support by the MARBEF Network of Excellence "Marine Biodiversity and Ecosystem Functioning", which is funded in the Community's Sixth Framework Programme (contract no. GOCE-CT-2003-505446). This publication contribution number is MPS-06009 of MarBEF. The work of G. Nehls is supported by the Regional Office of the Wadden Sea National Park of Schleswig-Holstein. Many thanks to all the people who gave helpful hands during fieldwork. Karsten Reise gave very valuable comments on the manuscript.

\section{References}

Ankel WE (1935) Die Pantoffelschnecke, ein Schädling der Auster. Nat Volk 65:173-176

Baird D, Asmus H, Asmus R (2004) Energy flow of a boreal intertidal ecosystem, the Sylt-Rømø Bight. Mar Ecol Prog Ser 279:45-61

Beukema JJ, Dekker R (2005) Decline of recruitment success in cockles and other bivalves in the Waden Sea: possible role of climate change, predation on postlarvae and fisheries. Mar Ecol Prog Ser 287:149-167

Blanchard M (1997) Spread of the slipper limpet Crepidula fornicata (L. 1758) in Europe. Current state and consequences. Sci Mar 61:109-118

Brinkman AG, Dankers N, van Stralen M (2002) An analysis of mussel bed habitats in the Dutch Wadden Sea. Helgol Mar Res 56:59-75

Buhs F, Reise K (1997) Epibenthic fauna dredged from tidal channels in the Wadden Sea of Schleswig-Holstein: spatial pattern and a long-term decline. Helgol Meeresunters 51:343359

Buroker NE (1985) Evolutionary patterns in the family Ostreidae: larviparity vs. oviparity. J Exp Mar Biol Ecol 90:233-247

Carlton JT, Thompson JK, Schemel LE, Nichols FH (1990) Remarkable invasion of San Francisco Bay (California, USA) by the Asian clam Potamocorbula amurensis. I. Introduction and dispersal. Mar Ecol Prog Ser 66:81-94

Colautti RI, Ricciardi A, Grigorovich IA, Macisaac HJ (2004) Is invasion success explained by the enemy release hypothesis? Ecol Lett 7:721-733

CWSS (Common Wadden Sea Secretariat) (1997) TMAP manual - the Trilateral Monitoring and Assessment Program. Common Wadden Sea Secretariat, Wilhelmshaven

Dame RF, Zingmark RG, Haskin E (1984) Oyster reefs as processors of estuarine materials. J Exp Mar Biol Ecol 83:239-247
Dankers N, Koelemaij K, Zegers J (1989) De role van de mossel en de mosselcultuur in het ecosysteem van de Waddenzee. RINRapport 89/9, Texel, 66 pp (in Dutch)

Dankers N, Herlyn M, Sand Kristensen P, Michaelis H, Millat G, Nehls G, Ruth M (1999) Blue mussels and blue mussel beds in the littoral. In: De Jong F, Bakker JF, van Berkel CJM, Dankers NMJA, Dahl K, Gätje C, Marencic H, Potel P (eds) Wadden Sea quality status report. Common Wadden Sea Secretariat, Wilhelmshaven, Germany, pp 141-145

Diederich S (2005a) Differential recruitment of introduced Pacific oysters and native mussels at the North Sea coast: coexistence possible? J Sea Res 53:269-281

Diederich S (2005b) High survival and growth rates of introduced Pacific oysters may cause restrictions on habitat use by native mussels in the Wadden Sea. J Exp Mar Biol Ecol. DOI: 10.1016/j.jembe.2005.07.012

Diederich S (2005c) Invasion of Pacific oysters (Crassostrea gigas) in the Wadden Sea: competitive advantage over native mussels. PhD thesis, University of Kiel

Diederich S, Nehls G, van Beusekom JEE, Reise K (2005) Introduced Pacific oysters (Crassostrea gigas) in the northern Wadden Sea: invasion accelerated by warm summers? Helgol Mar Res 59:97-106

Fréchette M, Butman CA, Geyer R (1989) The importance of boundary-layer flows in supplying phytoplankton to the benthic suspension feeder, Mytilus edulis L. Limnol Oceanogr 34:19-36

Herlyn M (2005) Quantitative assessment of intertidal blue mussel (Mytilus edulis L.) stocks: combined methods of remote sensing, field investigations and sampling. J Sea Res 53:243-253

Keane RM, Crawley MJ (2002) Exotic plant invasions and the enemy release hypothesis. Trends Ecol Evol 17:164-170

Kideys A (2002) Fall and rise of the Black Sea ecosystem. Science 297:1482-1484

Korringa P (1951) Crepidula fornicata as an oyster-pest. Rapp Procès-Verbaux d Réunions. Conseil permanent international pour l'exploration de la Mer II, vol 128, pp 55-59

Korringa P (1976) Farming the cupped oysters of the genus Crassostrea. Elsevier, Amsterdam

Mann R (1979) Some biochemical and physiological aspects of growth and gametogenesis in Crassostrea gigas and Ostrea edulis grown at sustained elevated temperatures. J Mar Biol Assoc UK 59:95-100

Maron JL, Vila M (2001) When do herbivores affect plant invasion? Evidence for the natural enemies and biotic resistance hypotheses. Oikos 95:361-373

de Montaudouin X, Audemard C, Labourg PJ (1999) Does the slipper limpet (Crepidula fornicata $\mathrm{L}$.) impair oyster growth and zoobenthos biodiversity? A revisited hypothesis. J Exp Mar Biol Ecol 135:105-124

Nehls G (2004) Miesmuschelmonitoring 1998-2002 im Nationalpark Schleswig-Holsteinisches Wattenmeer. Bericht an das Landesamt für den Nationalpark Schleswig-Holsteinisches Wattenmeer

Nehls G, Ketzenberg C (2002) Do common eiders Somateria mollissima exhaust their food resources? A study on natural mussel Mytilus edulis beds in the Wadden Sea. Dan Rev Game Biol 16:47-61

Nehls G, Ruth M (2004) Miesmuschelmonitoring und Miesmuschelmanagement im Nationalpark "Schleswig-Holsteinisches Wattenmeer" Berichtszeitraum 1997-2002. Bericht an das Landesamt für den Nationalpark Schleswig-Holsteinisches Wattenmeer und das Amt für Ländliche Räume, Kiel

Nehls G, Thiel M (1993) Large-scale distribution patterns of the mussel Mytilus edulis in the Wadden Sea of Schleswig-Holstein: do storms structure the ecosystem? Neth J Sea Res 31:181-187

Obert B, Michaelis H (1991) History and ecology of the mussel beds (Mytilus edulis L.) in the catchment area of a Wadden Sea tidal inlet. In: Elliot M, Ducrotoy J-P (eds) Esturaries and coasts: spatial and temporal intercomparisons. Olsen and Olsen, Fredensborg, pp 185-194

Orton JH (1927) Is the American slipper-limpet an oyster pest? Nautilus 40:102-103 
Peterson CH, Black R (1991) Preliminary evidence for progressive sestonic food depletion in incoming tide over a broad tidal sand flat. Estuar Coast Shelf Sci 32:405-413

Reise K (1985) Tidal flat ecology - an experimental approach to species interaction. Springer, Berlin Heidelberg New York

Reise K (1998) Pacific oysters invade mussel beds in the European Wadden Sea. Senckenb Marit 28:167-175

Reise K, Herre E, Sturm M (1994) Biomass and abundance of macrofauna in intertidal sediments of Königshafen in the northern Wadden Sea. Helgol Meeresunters 48:201-215

Reise K, Dankers N., Essink K (2005) Introduced species. In: Essink K, Dettmann C, Farke H, Laursen K, Lüerßen G, Marencic H, Wiersinga W (eds) Wadden Sea quality status report 2004. Common Wadden Sea Secretariat, Wilhelmshaven, pp $155-161$

Ruth M (1994) Untersuchung zur Biologie und Fischerei von Miesmuscheln im Nationalpark Schleswig-Holsteinisches Wattenmeer. Texte 73/97 des Umweltbundesamte, Berlin

Stachowicz JJ, Terwin JR, Whitlatch RB, Osman RW (2002) Linking climate change and biological invasions: ocean warming facilitates nonindigenous species invasions. Proc Natl Acad Sci USA 99:15497-15500

Stoddard P (2003) Reconstruction of blue mussel beds using aerial photographs from 1989 and 2002 of the North Frisian Wadden Sea, Germany, unpublished report. BioConsult SH, Hockensbüll

Strasser M (2002) Reduced epibenthic predation on intertidal bivalves after a severe winter in the European Wadden Sea. Mar Ecol Prog Ser 241:113-123

Strasser M, Günther C-P (2001) Larval supply of predator and prey: temporal mismatch between crabs and bivalves after a severe winter in the Wadden Sea. J Sea Res 46:57-67
Strasser M, Reinwald T, Reise K (2001) Differential effects of the severe winter of 1995/96 on the intertidal bivalves Mytilus edulis, Cerastoderma edule and Mya arenaria in the northern Wadden Sea. Helgol Mar Res 55:190-197

Thieltges DW (2005) Impact of an invader: epizootic American slipper limpet Crepidula fornicata reduces survival and growth in European mussels. Mar Ecol Prog Ser 286:13-19

Thieltges DW, Strasser M, Reise K (2003) The American slipper limpet Crepidula fornicata (L.) in the northern Wadden Sea 70 years after 1st introduction. Helgol Mar Res 57:27-33

Thieltges DW, Strasser M, van Beusekom JEE, Reise K (2004) Too cold to prosper-winter mortality prevents population increase of the introduced American slipper limpet Crepidula fornicata in northern Europe. J Exp Mar Biol Ecol 311:375-391

Torchin ME, Lafferty KD, Dobson AP, McKenzie VJ, Kuris AM (2003) Introduced species and their missing parasites. Nature 421:628-630

de Vlas J, Dankers N, Brinkman B, Steenbergen J, Millat G, Herlyn M, Wehrman A, Nehls G, Ruth M, Buschbaum C, Kristensen PS (2005) Intertidal blue mussel beds. In: Wadden Sea quality status report 2004. Wadden Sea ecosystem no. 19

Walne PR (1956) The biology and distribution of the slipper limpet Crepidula fornicata in Essex rivers. Fish Invest Ser II 20:1-50

Wehrmann A, Herlyn M, Bungenstock F, Hertweck G, Millat G (2000) The distribution gap is closed-first record of naturally settled Pacific oysters (Crassostrea gigas) in the East Frisian Wadden Sea, North Sea. Senckenb Marit 30:153-160

Werner B (1948) Die amerikanische Pantoffelschnecke Crepidula fornicata L. im nordfriesischen Wattenmeer. Zool Jahrb Abt Syst Ökol Geogr Tiere 77:449-488 